\title{
Early Childhood Development - The Role of The Paediatrician
}

\section{Erken Çocukluk Geliş̧imi - Çocuk Hekiminin Rolüi}

\author{
Elif Nursel Özmert ${ }^{1}$ (D)
}

${ }^{1}$ Hacettepe University Faculty of Medicine, Divisions of Social Pediatrics and Developmental Pediatrics, Department of Pediatrics, Ankara, Turkey

ORCID ID: E.N.Ö. 0000-0002-4911-9200

Citation/Atff: Ozmert EN. Early Childhood development - the role of the paediatrician. Çocuk Dergisi - Journal of Child 2021;21(3):288-292.

https://doi.org/10.26650/jchild.2021.998879

\section{ABSTRACT}

Early childhood development is the physical, cognitive, linguistic, and socioemotional development of young children until primary school. Although a child right, unfortunately many children cannot reach their developmental potential. A pediatrician is a physician who is concerned primarily with the health, welfare, and development of children. Pediatricians have the responsibility to promote early childhood development as well as developmental surveillance and screening for early diagnosis. The WHO/UNICEF Nurturing Care framework has specified 5 main strategies/domains: health, nutrition, responsive care giving, secure-safe environment and early education opportunities for early childhood development. The pediatrician plays the role of service provider, advocate, researcher or educator in all these domains. All these domains can only be successfully fulfilled through multidisciplinary collaboration, a way of working that pediatricians are accustomed to using.

Keywords: Early childhood development, nurturing care, primary pediatric care, pediatrician

\section{INTRODUCTION}

Early childhood development is a child rights issue which is important for the future of the planet and which requires multidisciplinary intervention. This review will focus on the role of the pediatrician, but will keep in mind the multidisciplinary characteristics of all the interventions.

Pediatrics was defined as a separate specialization in the late $19^{\text {th }}$ century and the focus was nutrition, infectious diseases and prevention of mortality. Later, in the middle of the $20^{\text {th }}$ century, several developmental and behavioral issues as well as chronic diseases were recognized as "new morbidities". By the end of the century "newer morbidities" such as mood disorders, substance abuse, and exposure to violence were
Öz

Erken çocukluk gelişimi çocukların ilkokul dönemine kadar olan fiziksel, bilişsel, dil ve sosyoduygusal gelişimini içerir. Temel bir çocuk hakkı olmasına karşın ne yazık ki pekçok çocuk doğuştan getirdiği potansiyeline erişememektedir. Çocuk hekimi, temel olarak çocuğun sağlığı, refahı ve gelişimi ile ilgilenen hekimdir. Çocuk hekiminin erken çocukluk gelişimini desteklemenin yanı sıra, gelişimsel izlem ve tarama ile erken tanı koyma sorumluluğu da vardır. DSÖ/UNICEF'in "geliştiren bakım" çerçeve programı erken çocukluk gelişimi için 5 temel alan belirlemiştir; sağıı, beslenme, duyarlı bakım, güvenli-güvenilir çevre ve erken eğitim olanaklarına erişim. Çocuk hekiminin hizmet sunucu, savunucu, araştırmacı ve eğitimci olarak tüm bu alanlarda görev ve sorumlulukları vardır. Tüm bu alanlardaki çalışmalar çocuk hekimlerinin çok yatkın olduğu mulidisipliner işbirliği ile başarılabilir.

Anahtar Kelimeler: Erken çocukluk gelişimi, geliştiren bakım, çocuk hekimi

also recognized. Most recently, increasingly complex mental health concerns; the adverse effects of television viewing; the influence of new technologies; epidemic increases in obesity; and persistent economic, racial, and ethnic disparities in health status have been labelled the "millennial morbidities" (1). However it should be kept in mind that, especially in lowand middle-income countries (LMIC), pediatricians continue to encounter the "older morbidities" alongside the millennial morbidities.

Pediatrics and a pediatrician are currently defined by the American Academy of Pediatrics as follows: (2)

"Pediatrics is the specialty of medical science concerned with the physical, mental, and social health of children from birth 
to young adulthood. Pediatric care encompasses a broad spectrum of health services ranging from preventive health care to the diagnosis and treatment of acute and chronic diseases. Pediatrics is a discipline that deals with biological, social, and environmental influences on the developing child and with the impact of disease and dysfunction on development. A pediatrician is a physician who is concerned primarily with the health, welfare, and development of children and is uniquely qualified for these endeavors by virtue of interest and initial training". In this definition, not only treatment but also preventive pediatric primary care services, welfare of the child, mental and social health and development are areas defined as responsibilities for pediatricians. However, in different countries, the preventive pediatric primary health care services can be delivered by other health care personnel (3). Even when other health care personnel deliver primary preventive care, the role of the pediatrician for preventive health care services continues through collaboration, research, and advocacy.

Then comes the definition of childhood development:

"Childhood development is a maturational and interactive process, resulting in an ordered progression of perceptual, motor, cognitive, language, socio-emotional, and selfregulation skills. The acquisition of skills and learning in middle childhood, throughout adolescence, and into adulthood builds on foundational capacities established between preconception and early childhood, with multigenerational effects" (4). Here it is important to emphasize brain development, interactions, and education as primary factors, as well as the other factors affecting brain development, interactions, and education.

However, we will limit our discussion with early childhood development (ECD), which is defined as:

"The physical, cognitive, linguistic, and socioemotional development of young children until they transition to primary school (typically around age 6 or 7). The first phase of human development (starting during pregnancy), ECD is an integrated concept that cuts across multiple sectors, including health and nutrition, education, and social protection" (5). The field of early childhood development is framed by the United Nations Convention on the Rights of the Child in several articles (6).

When discussing ECD, two questions arise - how early and why early? Developmental physiology starting from the developmental origins of health and disease hypothesis provides an answer. The Barker hypothesis first defined the developmental origins of adulthood diseases. Now it has been broadened to encompass the developmental origins of health and disease including the interaction of several nutritional and environmental factors and the genetic make-up of the offspring (7). So the health and disease of the parents will determine the health and disease of the baby. The pediatrician has an intergenerational role to play, as do family centered practices.

While development is a continuous process throughout childhood and life, timing is still crucial. The interaction between genes, environment, and age will again determine the developmental outcome postconceptionally (8). Neurodevelopment proceeds by a scaffolding process in which the development of increasingly complex neural circuits relies on successful completion of previous stages of development. Thus, optimal, healthy neurobehavioral development requires that all necessary factors be present at their biologically defined time points and that no inhibitory factors be present. The most active period of neurologic development occurs in the first 1000 days of life, the period beginning at conception and the first 2 years of life (9).

Environment in this context could be classified as nutrition, social interactions with the parents, family, friends, and teacher, as well as opportunities to learn and play and any kind of environmental hazards.

Intervention known to effectively improve early childhood development from the Lancet series (10) on advancing early childhood development has been given in the Table 1. Among the listed 17 interventions shown to be effective, 10 are directly related to pediatric practices and 7 are subjects the pediatrician should collaborate on, search for, and advocate. As for a supportive policy environment, all items are related to pediatric practices, and 3 are directly related to patient care (Table 1).

So for early childhood development, multiple factors are effective. It has been estimated that 250 million children younger than 5 years of age in low- and middle-income countries are at risk of not reaching their developmental potential (4). The main reasons are poverty and stunting. WHO and UNICEF covered these factors under the "nurturing care" framework in 2018 (11). The five main factors are health, nutrition, security and safety, responsive care giving, and early learning. These multiple factors are also related to multiple sectors. However physicians and especially pediatricians are among the key personnel. Pediatricians have a role in all these sectors as service provider, researcher, educator, and advocate. This should include children, families, students, other health care providers, communities, and policy makers. They should act individually as well as through professional societies.

Recently, the Indian Academy of Pediatrics released two consensus papers defining the role of pediatrician in ECD and as well as nurturing care $(12,13)$.

As service providers. pediatricians can get in contact with the family and child before birth. So starting from antenatal care. pediatricians have the opportunity to promote early childhood development. The following table gives some examples of the role of the pediatrician as a service provider (Table 2 ).

Nutrition is a vital component of health and disease, morbidity and mortality, as well as brain development. Protein, specific fats (e.g., long chain polyunsaturated fatty acids), glucose, micronutrients (zinc, copper, iodine, iron, selenium), vitamins and cofactors (vitamin B, vitamin A, vitamin $K$, folate, and choline) are essential. Among these, protein, LC-PUFAs, iodine, iron, zinc, copper, folate, and choline, although always needed, 
Table 1: Examples of interventions known to effectively improve early childhood development (10)

\section{Interventions}

- Iodine supplementation before or during pregnancy

- Antenatal corticosteroids for women at risk of preterm birth

- Magnesium sulphate for women at risk of preterm birth

- Antiplatelet agents for women at risk of pre-eclampsia

- Delayed cord clamping

- Therapeutic hypothermia for hypoxic ischemic encephalopathy

- Kangaroo Mother Care for small infants (e.g., birthweight <2000 g)

- Breastfeeding and complementary feeding promotion, education, and support

- Responsive caregiving with simulation and early learning opportunities

- Iron and multiple micronutrient supplementation for infants and children

- Deworming

- Treatment of moderate and severe acute malnutrition

- Interventions for common (parental) mental disorders including in the perinatal period

- Smoking cessation interventions

- Elimination of environmental toxins (e.g., lead, mercury, pesticides)

- Parent support programs

- Early childhood care and education

Examples of supportive policy environment

- Paid parental leave and paid sick leave to enable parents to provide care

- Breastfeeding breaks at work

- Paid sick leave to enable parents to provide nurturing care

- Minimum wage sufficient to lift families out of poverty

- Tuition-free pre-primary education

- Poverty alleviation strategies

Adapted from reference 10

Table 2: The role of the pediatrician for early childhood development as a service provider (14)

\begin{tabular}{ll}
\hline Antenatal care & $\begin{array}{l}\text { promotion of healthy lifestyles; attention to maternal mental health and potential exposure to interpersonal } \\
\text { violence; father's engagement; counselling on breast feeding and nurturing care, including responsive caregiving. }\end{array}$ \\
Postnatal care & $\begin{array}{l}\text { Esential interventions for the newborn including skin-to-skin contact; support for early initiation and exclusive } \\
\text { breastfeeding; kangaroo care for low-birth-weight infants; attention to maternal mental health, particularly } \\
\text { postpartum depression, and potential exposure to interpersonal violence; counselling on nurturing care, including } \\
\text { neonatal screening, responsive caregiving, as well as danger signs for illness or malnutrition; rooming-in. }\end{array}$
\end{tabular}

Well child visit $\quad$ additional age appropriate screening micronutrient supplementation; growth and development monitoring; identification of children at risk of sub-optimal development; immunization; counseling on infant and young child feeding, responsive feeding, prevention of illness and care-seeking; age appropriate and safe play materials and books; attention to the prevention of unintentional injuries and child maltreatment; health promotion classes; referral to other sectors such as social protection.

Sick child visit

Counseling on infant and young child feeding during and after illness; follow-up visits for growth and development monitoring; identification and referral of families and children at risk of sub-optimal development, or poor mental health and/or maltreatment

Adapted from reference 14

are also especially important during the critical and sensitive early development period (15).

Toxic stress is another important environmental threat to development. Physical, sexual, or emotional abuse and neglect can lead to toxic stress, which will end up in a change in the brain architecture with fewer neurons, less synapsis, and an altered neurotransmitter system. As a result, learning, memory, educational achievement, job opportunities, and socioeconomic status will be adversely affected, in addition to other disadvantages (16). So both preventing toxic stress and supporting responsive care giving are needed for optimal development.
It has been estimated that in the USA, the total amount of IQ loss due to environmental toxins is much more in preterm births (17). Pediatricians should be aware of the silent environmental toxin pandemic.

However, not only prevention of adverse factors but also promotion of early childhood development should be in the context of pediatrics. Starting with responsive care giving, play and reading should be promoted.

ECD will bring the child to school readiness, but it should be kept in mind that childhood development continues, as does the role of the pediatrician, in middle childhood and adolescence. 


\section{Developmental Surveillance and Screening}

In addition to promotion of early childhood development for all children, pediatricians have a role in early identification and intervention for developmental disorders, which is possible through developmental surveillance and screening. As mentioned above, screening for diseases and disorders, such as inborn errors of metabolism and hypothyroidism, as well as hearing and vision, that may affect development is vital. However, development should also be screened. All child health supervision or well baby follow-up visits should incorporate developmental surveillance. If there is a developmental concern at any age and for all children at 9, 18, and 24-30 months of age, surveillance should be supported by developmental screening, which is the use of standardized tools to identify and refine any developmental risk (18).

However, despite recommendations, developmental screening has not become universal in the USA. American Academy of Pediatrics surveys of pediatricians report screening rates of $23 \%$ in $2002,45 \%$ in 2009 , and $63 \%$ in 2016 . Pediatricians have reported difficulties in incorporating multiple new guidelines for related conditions into their practices and continue to report time limitations and inadequate payment as barriers to implementation (18).

Unfortunately, a study in Turkey has revealed that developmental concerns are not addressed satisfactorily. $87.1 \%, 48.7 \%$, and $34.5 \%$ of parents in primary health care centers where family physicians are in charge, in university hospital outpatient clinics, and in state hospital outpatient clinics where pediatricians are in charge, respectively, reported that developmental issues had been discussed during their appointments $(p=0.000)$. Nearly one third of families reported at least one developmental concern. Less than half of the concerned parents had visited a health center for these concerns (19).

Pediatricians in the USA report time limitations and inadequate payment as barriers to implementation of universal screening (18). In addition to developmental screening, specific screening is also now recommended (18). However in a study it was reported that nearly $20 \%$ of pediatricians agreed that screening for social-emotional risk factors is beyond the scope of the pediatric medical home. At least half of pediatricians endorsed the three perceived barriers as being moderate or significant: a lack of practice-friendly tools to promote healthy parent-child relationships (50\%), a lack of practice-friendly tools to assess the family environment for social-emotional risk factors (60\%), and a lack of community resources available to address family social-emotional issues (67\%) (20).

In a study conducted in a single center in Ankara, Turkey, pediatric residents mostly stated that they didn't have enough knowledge about child development and they didn't use a tool for developmental screening or evaluation. Time strain was listed as the most significant barrier (21).

So although by definition developmental screening and early diagnosis of developmental disorders are among the primary responsibilities of pediatricians, further empowerment is needed.

Pediatricians can incorporate recent advances in developmental science into effective interventions for the child, home, clinic, and community. They have a developmental approach to health, and understand the importance of prevention as well as effective advocacy. However there is a need to emphasize early childhood development, nurturing care, and the role of the pediatrician during training. Also, further research is needed to demonstrate evidence-based intervention strategies for different socioeconomic and cultural groups. The skills of pediatricians for advocacy should also be promoted (22).

\section{CONCLUSION}

The role of the pediatrician in early childhood development is essential. Not only are the pediatric holistic approach to the child (biopsychosocial) and to the family (genetic, socioeconomic, cultural) crucial in guiding families, but so is the intergenerational perspective. Pediatric visits are opportunities for developmental enhancement, screening, and surveillance, family engagement (including the father), anticipatory guidance, and the creation of therapeutic alliances with families. Pediatricians have a role in the identification of those children at high risk for poor development, providing positive parenting support for all families to assist them with development, and providing referrals for additional support when necessary. Pediatricians are not only service providers. They are also advocates of children, child rights, and child health and welfare, as well as development. They are in multidisciplinary collaboration as service providers, as advocates, as researchers, and as policy makers, which is needed to achieve the goals $(23,24)$.

Hakem Değerlendirmesi: Dış bağımsız.

Çıkar Çatışması: Yazar çıkar çatışması beyan etmemiştir.

Finansal Destek: Yazar finansal destek beyan etmemiştir.

Peer Review: Externally peer-reviewed.

Conflict of Interest: Author declared no conflict of interest.

Financial Disclosure: Author declared no financial support.

\section{REFERENCES}

1. Shonkoff JP, Garner AS, The Committee on Psychosocial Aspects of Child and Family health, Committee on Early Childhood, Adoption, and Dependent Care, and Section on Developmental and Behavioral Pediatrics. The Lifelong Effects of Early Childhood Adversity and Toxic Stress. Pediatrics 2012;129;e232

2. Commitee on Pediatric Workforce. Definition of a Pediatrician. Pediatrics 2015;135:780.

3. van Esso D, del Torso S, Hadjipanayis A, Biver A, Jaeger-Roman E, Wettergren $B$,et al. Paediatric primary care in Europe: variation between countries. Arch Dis Child 2010;95:791-5. 
4. Black MM, Walker SP, Fernald LCH, Andersen CT, DiGirolamo AM, Lu C, et al. Early childhood development coming of age: science through the life course. Lancet 2017;389:77-90.

5. Naudeau S, Kataoka N,Valerio A, Neuman MJ, Kennedy Elder L. Investing in Young Children An Early Childhood Development Guide for Policy Dialogue and Project Preparation. The World Bank Washington DC, 2011.

6. Uchitel J, Alden E, Bhutta ZA, Goldhagen J, Narayan AP, Raman S, et al. The Rights of Children for Optimal Development and Nurturing Care. Pediatrics 2019;144(6):e2019048.

7. Hanson MA, Gluckman PD. Early Developmental Conditioning of Later Health and Disease: Physiology or Pathopysiology? Physiol Rev 2014;94:1027-76.

8. Boyce WT, Levitt P, Martinez FD, McEwen BS, Shonkoff JP. Genes. Environments, and Time: The Biology of Adversity and Resilience. Pediatrics 2021;147(2):e20201651.

9. Schwarzenberg SJ, Georgieff MK, AAP Comittee on Nutrition. Advocacy for Improving Nutrition in the First 1000 Days To Support Childhood Development and Adult Health. Pediatrics 2018;141(2):e20173716.

10. Linda M Richter, Bernadette Daelmans, Joan Lombardi, Jody Heymann, Florencia Lopez Boo, Jere R Behrman. Advancing Early Childhood Development: from Science to Scale 3 Lancet 2017;389:103-18.

11. World Health Organization, United Nations Children's Fund, World Bank Group. Nurturing care for early childhood development: a framework for helping children survive and thrive to transform health and human potential. Geneva: World Health Organization; 2018.

12. Bharadva K, Shastri D, Gaonkar N, Thakre R, Mondkar J, Nanavati $\mathrm{R}$, et al. Consensus Statement of Indian Academy of Pediatrics on Early Childhood Development. Indian Pediatr 2020;57:834-41.

13. Mukherjee SJ, Agrawal D, Mishra D, Shastri D, Dalwai $\mathrm{SH}$, Chattopadhyay N, et al. Indian Academy of Pediatrics Position Paper on Nurturing Care for Early Childhood Development. Indian Pediatr 2021 Jun 28;S097475591600349.

14. World Health Organization, United Nations Children's Fund, World Bank Group. Operationalizing Nurturing Care for Early Childhood Development. The role of the health sector alongside other sectors and actors. Geneva, 2019.
15. Georgieff MK, Brunette KE, Tran PV. Early life nutrition and neural plasticity. Dev Psychopathol 2015;27:411-23.

16. Radley JJ, Sisti HM, Hao J, Rocher AB, McCall T, Hof PR, et al. Chronic behavioral stress induces apical dendritic reorganization in pyramidal neurons of the medial prefrontal cortex. Neuroscience 2004;125(1):1-6.

17. Grandjean P, Landrigan PL.Neurobehavioural effects of developmental toxicity Lancet Neurol 2014;13:330-8.

18. Lipkin PH, Macias MM, AAP Council on Children with Disabilities, Section on Developmental and Behavioral Pediatrics. Promoting Optimal Development: Identifying Infants and Young Children With Developmental Disorders Through Developmental Surveillance and Screening. Pediatrics 2020;145(1):e20193449.

19. Çelen Yoldaş T, Özmert EN, Bayazıt Y, Tanrıkulu B, Yetim H, Çakır B. Developmental Concerns, Parental Perceptions and Missed Opportunities from Different Levels of Health Centers in a MiddleIncome Country. Indian J Pediatr 2021;88(1):16-22.

20. Garner AS, Storfer-Isser A, Szilagyi M, Stein REK, Green CM, Kerker $B D$, et al. Promoting Early Brain and Child Development: Perceived Barriers and the Utilization of Resources to Address Them. Acad Pediatr 2017;17:697-705.

21. Çelen Yoldaş T, Şenel S, Abuş HM, Yücel H, Özmert EN. Identification of the Place of Developmental Issues in the Educational and Clinical Practices of Pediatric Residents and Affecting Factors Turkish J of Pediatric Disease 2021;15:59-64.

22. Committee on Psychosocial Aspects of Child and Family Health, Committee on Early Childhood, Adoption and Dependent Care, and Section on Developmental and Behavioral Pediatrics. Early Childhood Adversity, Toxic Stress, and the Role of the Pediatrician: Translating Developmental Science Into Lifelong Health. Pediatrics 2012;129:e224-e231.

23. Rushton FE, Kraft C. Building brains, forging futures: the pediatrician's role. International Journal of Pediatrics and Adolescent Medicine 2014;1:3-7.

24. Yogman M, Garfi eld CF, AAP the Committee on Psychosocial Aspects of Child Health. Fathers' Roles in the Care and Development of Their Children: The Role of Pediatricians. Pediatrics 2016;138(1):e20161128. 